\title{
Partial Nephrectomy for TIb Renal Cell Carcinoma: A Safe and Superior Treatment Option
}

\author{
Ross J. Mason, MD; Ricardo A. Rendon, MD, FRCSC
}

Department of Urology, Dalhousie University and QEIl Health Sciences Centre, Halifax, NS

I $\mathrm{n}$ recent decades, rapid advances in the surgical management of localized renal cell carcinoma (RCC) have taken place. Partial nephrectomy (PN) has supplanted radical nephrectomy $(\mathrm{RN})$ as the treatment of choice for $\mathrm{T} 1 \mathrm{a}$ renal masses with comparable oncological outcomes and the added benefits of renal preservation. ${ }^{1-3}$ Although initially reserved for these small renal masses and for imperative indications, PN has been successfully extended to T1b and larger renal masses.

When undergoing treatment for RCC, most patients have three main goals: (1) to be cured from cancer; (2) to have minimal risk of complications; and (3) if at all possible, to have their surgery performed via minimally invasive strategies. The first goal, achieving long-term cancer control, is usually the most pressing concern. For T1b renal masses, $\mathrm{PN}$ has been shown to be equivalent to $\mathrm{RN}$ in terms of cancer specific outcomes..$^{4-9}$ In the largest published study to date, Badalato and colleagues used the Surveillance, Epidemiology, and End Results (SEER) database to retrospectively compare $\mathrm{PN}$ and $\mathrm{RN}$ for $\mathrm{T} 1 \mathrm{~b}$ renal masses. ${ }^{4}$ They included 11256 patients (1047 who underwent PN) with a median follow-up of close to 3 years. When controlling for several clinical factors, no difference was found in cancer specific survival (CSS) or overall survival (OS) between treatment groups. This finding held true even when stratifying by tumour size and patient age. Similarly, in a recent 15 -year systematic review performed by El-Ghazaly and Rendon investigating survival rates among patients undergoing PN and $\mathrm{RN}$ for renal masses $>4 \mathrm{~cm}$, the predicted 5-year CSS rates for those with $\mathrm{T} 1 \mathrm{~b}$ renal masses were $97 \%$ and $90 \%$, respectively. ${ }^{10}$ From these studies, among others, it is clear that $\mathrm{PN}$ is an effective treatment for $\mathrm{T} 1 \mathrm{~b}$ renal masses with no sacrifice in cancer specific outcomes when compared with RN.

Limiting the morbidity associated with undergoing treatment is the second most important goal among patients with
RCC. When considering the preservation of renal function, PN provides significant advantages over RN. Decreased renal function is associated with an increased risk of several disease states, including metabolic derangements, anemia and cardiovascular disease and it is independently associated with an increased risk of all cause mortality. ${ }^{11-15}$ Therefore, when treating RCC, the preservation of renal function becomes paramount. Several studies have shown that $\mathrm{PN}$ results in a smaller decrease in renal function and a decreased risk of developing chronic renal failure when compared with RN. , $^{8,-20}$ In a study by Huang and colleagues including 647 patients (385 who underwent PN), only 2.9\% who underwent $\mathrm{PN}$ had new-onset of glomerular filtration rate $(\mathrm{GFR})<45 \mathrm{~mL} / \mathrm{min} / 1.73 \mathrm{~m}^{2}$ postoperatively compared with $35.8 \%$ who underwent RN. ${ }^{16}$ This amounted to a hazard ratio (HR) of 11.8 for the development of GFR $<45 \mathrm{~mL} /$ $\mathrm{min} / 1.73 \mathrm{~m}^{2}$ even after controlling for age, comorbidities and preoperative GFR. Although this study looked specifically at T1a renal masses, this association remains when considering only $\mathrm{T} 1 \mathrm{~b}$ renal masses. In a study by Weight and colleagues, a postoperative decline in GFR of $16.6 \%$ and $23.5 \%$ was observed in 212 and 298 patients undergoing $\mathrm{PN}$ and RN for T1b renal masses, respectively. ${ }^{17}$

Unsurprisingly, the preservation of renal function associated with PN has resulted in decreased long-term morbidity and mortality. In a study by Huang and colleagues, including 3659 patients undergoing RN and 556 undergoing PN for T1a renal masses, the incidence of cardiac events during follow-up was $40 \%$ greater among patients undergoing RN. ${ }^{21}$ There was also an increased risk of all-cause mortality among those undergoing RN (HR 1.38, $p<0.001)$. Again, this finding has been extended to $T 1 b$ renal masses. In the above mentioned study by Weight and colleagues, including only $\mathrm{T} 1 \mathrm{~b}$ renal masses, the excess loss of renal function attributed to $\mathrm{RN}$ was associated with a $25 \%$ increased risk of cardiac death and a $17 \%$ increased risk of all-cause mortality, although CSS was equivalent among PN and RN groups. ${ }^{17}$ 
Although PN results in decreased long-term morbidity when compared with $\mathrm{RN}$, the incidence of perioperative complications may be slightly higher. In a prospective, randomized trial by van Poppel and colleagues, there was an increased incidence of hemmorhage (3.1\% vs. $1.2 \%)$, urinary fistulae ( $4.4 \%$ vs. $0 \%$ ) and re-operation ( $4.4 \%$ vs. $2.4 \%)$ in patients who underwent PN compared to those who underwent RN. ${ }^{22}$ This remains an area for significant debate, as other authors have found no difference in perioperative complication rates. In a 2007 meta-analysis by Lesage and colleagues, a trend towards increased perioperative complication rates in those undergoing $\mathrm{PN}$ was identified, but it did not reach statistical significance. ${ }^{23}$ Nonetheless, the overall risk of suffering a severe perioperative complication remains low regardless of treatment type and will likely decrease further with the refinement of surgical techniques.

The third major goal among patients undergoing treatment for RCC is to have their procedure performed with minimally invasive techniques. Fortunately, recent studies have reported favourable outcomes when treating $\mathrm{T} 1 \mathrm{~b}$ renal masses with laparoscopic and robotic strategies. ${ }^{8,24,25}$ For example, in a study by Lifshitz and colleagues comparing laparoscopic $\mathrm{PN}$ for $\mathrm{T} 1 \mathrm{a}$ and $\mathrm{T} 1 \mathrm{~b}$ renal masses, no difference was found in operative time, warm ischemia time, blood loss or intraoperative complications, although postoperative complication rates were higher in the T1b group. ${ }^{25}$ The nephron-sparing benefits of PN have also been shown when using minimally invasive techniques for $\mathrm{T} 1 \mathrm{~b}$ tumours. Comparing laparoscopic $\mathrm{PN}$ to $\mathrm{RN}$ for $\mathrm{T} 1 \mathrm{~b}$ renal masses, Deklaj and colleagues found a postoperative decline in GFR of $12.5 \%$ and $29.3 \%$, respectively. ${ }^{8}$ Thus, it appears that minimally invasive $\mathrm{PN}$ is safe and beneficial in the treatment of T1b renal masses. As experience grows and surgical training programs place a greater focus on minimally invasive approaches, the benefits of minimally invasive PN will likely continue to increase.

Although the bulk of existing evidence suggests that PN is an effective and advantageous treatment for all $\mathrm{T} 1$ renal masses, there is a small body of evidence suggesting that patients undergoing $\mathrm{PN}$ have a slightly increased risk of allcause mortality compared with those undergoing RN. In the above mentioned randomized trial by van Poppel and colleagues, 10-year OS was greater for patients undergoing RN compared with PN $(81.1 \%$ vs $75.7 \%, p=0.03) .{ }^{26}$ In the subgroup of patients with proven RCC, however, this result did not maintain statistical significance and $\mathrm{RN}$ and $\mathrm{PN}$ provided excellent oncological outcomes, with only 12 RCC-related deaths in the entire study population. Furthermore, the planned accrual for this study was over 1300 patients, but only 541 patients were actually enrolled. It is hypothesized that many patients refused to partake in this trial and only a subset of eligible patients was included, imparting a selection bias. Finally, during this study period it was believed that the thickness of the surgical margin was correlated with oncological outcomes. Therefore, it is likely that more renal parenchyma was removed than would be today, reducing the nephron-sparing benefits of PN.

In the modern treatment of RCC, the weight of evidence shows clear advantages to performing $\mathrm{PN}$ for $\mathrm{T} 1 \mathrm{~b}$ renal masses. It results in superb oncological outcomes which are comparable to those achieved with $\mathrm{RN}$ and can be safely performed through open and minimally invasive approaches. Although there may be a small increase in perioperative complications associated with $\mathrm{PN}$, this is outweighed by the significant long-term gains provided by the preservation of renal function. When treating $\mathrm{T} 1 \mathrm{~b}$ renal masses, $\mathrm{PN}$ should be the preferred treatment option.

Competing interests: None declared.

This paper has been peer-reviewed.

\section{References}

1. Greene FL, Gospodarowicz MK, Wittekend C. American Joint Committee on Cancer (AJCC) Staging Manual. 7th edn. Philadelphia, PA: Springer 2009.

2. Liungberg B, Cowan NC, Hanbury DC, et al. EAU guidelines on renal cell carcinoma: the 2010 update. Eur Urol 2010;58:398-406.

3. Campbell SC, Novick AC, Belldegrun A, et al. Guideline for management of the clinical TI renal mass. J Urol 2009;182:1271-9. http://dx.doi.org/10.1016/i.juro.2009.07.004

4. Badalato GM, Kates M, Wisnivesky JP, et al. Survival after partial and radical nephrectomy for the treatment of stage TIbNOMO renal cell carcinoma (RCC) in the USA: a propensity scoring approach. BJU Int 2011; . Epub 2011 Sept 20.

5. Antonelli A, Ficarra V, Bertini $R$, et al. Elective partial nephrectomy is equivalent to radical nephrectomy in patients with clinical $\mathrm{Tl}$ renal cell carcinoma: results of a retrospective, comparative, multi-nstitutional study. BJU Int 2012;109:1013-8. http://dx.doi.org/10.1111/i.1464-410X.2011.10431.x. Epub 2011 Aug 24.

6. Crépel $M$, Jeldres $C$, Sun $M$, et al. A population-based comparison of cancer-control rates between radical and partial nephrectomy for T1A renal cell carcinoma. Urology 2010;76:883-8. http://dx.doi. org/10.1016/i.urology.2009.08.028

7. Leibovich BC, Blute ML, Cheville JC, et al. Nephron sparing surgery for appropriately selected renal cell carcinoma between 4 and $7 \mathrm{~cm}$ results in outcome similar to radical nephrectomy. J Urol 2004; 171:106670. http://dx.doi.org/10.1097/01.ju.0000113274.40885.db

8. Deklaj T, Lifshitz DA, Shikanov SA, et al. Laparoscopic radical versus laparoscopic partial nephrectomy for clinical TIbNOMO renal tumors: comparison of perioperative, pathological, and functional outcomes. J Endourol 2010;24:1603-7. hitp://dx.doi.org/10.1089/end.2009.0312

9. Simmons $M N$, Weight CJ, Gill IS. Laparoscopic radical versus partial nephrectomy for tumors $>4 \mathrm{~cm}$ : intermediate-term oncologic and functional outcomes. Urology 2009;73:1077-82. http://dx.doi. org/10.1016/i.urology.2008.11.059

10. El-Ghazaly TH, Rendon RA. Oncological outcomes of partial nephrectomy for tumors greater than 4-cm: A 16 year systematic review. 2012. Manuscript in preparation.

11. Go AS, Chertow GM, Fan D, et al. Chronic kidney disease and the risks of death, cardiovascular events, and hospitalization. N Engl J Med 2004;351:1296-305. http://dx.doi.org/10.1056/NEJMoa041031

12. Fried LF, Katz R, Sarnak MJ, et al. Kidney function as a predictor of noncardiovascular mortality. J Am Soc Nephrol 2005; 16:3728-35. http://dx.doi.org/10.1681/ASN.2005040384

13. Coresh J, Astor B, Sarnak MJ. Evidence for increased cardiovascular disease risk in patients with chronic kidney disease. Curr Opin Nephrol Hypertens 2004;13:73-81. http://dx.doi.org/10.1097/00041552200401000-00011

14. Sarnak MJ, Levey AS, Schoolwerth AC, et al. Kidney disease as a risk factor for development of cardiovascular disease: a statement from the American Heart Association Councils on Kidney in Cardiovascular Disease, High Blood Pressure Research, Clinical Cardiology, and Epidemiology and Prevention. Hypertension 2003;42:1050-65. http://dx.doi.org/10.1161/01.HYP.0000102971.85504.7c 
Mason et al.

15. Weiner DE, Tighiouart $H$, Amin MG, et al. Chronic kidney disease as a risk factor for cardiovascular disease and all-cause mortality: a pooled analysis of community-based studies. J Am Soc Nephrol 2004; 15:130715. http://dx.doi.org/10.1097/01.ASN.0000123691.46138.E2

16. Huang WC, Levey AS, Serio AM, et al. Chronic kidney disease after nephrectomy in patients with renal cortical tumours: a retrospective cohort study. Lancet Oncol 2006;7:735-40. http://dx.doi.org/10.1016/ S1470-2045(06)70803-8

17. Weight CJ, Larson BT, Fergany AF, et al. Nephrectomy induced chronic renal insufficiency is associated with increased risk of cardiovascular death and death from any cause in patients with localized cTlb renal masses. J Urol 2010;183:1317-23. http://dx.doi.org/10.1016/i.juro.2009.12.030

18. Snow DC, Bhayani SB. Rapid communication: chronic renal insufficiency after laparoscopic partial nephrectomy and radical nephrectomy for pathologic tla lesions. J Endourol 2008;22:337-41. http://dx.doi. org/10.1089/end.2007.0240

19. Mckiernan J, Simmons R, Katz J, et al. Natural history of chronic renal insufficiency after partial and radical nephrectomy. Urology 2002;59:816-20. htrp://dx.doi.org/10.1016/S0090-4295(02)01501-7

20. Lau WK, Blute ML, Weaver AL, et al. Matched comparison of radical nephrectomy vs nephron-sparing surgery in patients with unilateral renal cell carcinoma and a normal contralateral kidney. Mayo Clin Proc 2000;75:1236-42. http://dx.doi.org/10.4065/75.12.1236

21. Huang WC, Elkin EB, Levey AS, et al. Partial Nephrectomy vs. Radical Nephrectomy in Patients With Small Renal Tumors: Is There a Difference in Mortality and Cardiovascular Outcomes? J Urol 2009;181:55-62. http://dx.doi.org/10.1016/i.juro.2008.09.017

22. Van Poppel H, Da Pozzo L, Albrecht W, et al. A prospective randomized EORTC intergroup phase 3 study comparing the complications of elective nephron-sparing surgery and radical nephrectomy for low-stage renal cell carcinoma. Eur Urol 2007;51:1606-15. http://dx.doi.org/10.1016/i.eururo.2006.11.013
23. Lesage $K$, Joniau $S$, Fransis $K$ et al. Comparison between open partial and radical nephrectomy for renal tumours: perioperative outcome and health-related quality of life. Eur Urol 2007;51:614-20. http:// dx.doi.org/10.1016/j.eururo.2006.10.040

24. Patel MN, Krane $L S$, Bhandari A, et al. Robotic partial nephrectomy for renal tumors larger than $4 \mathrm{~cm}$. Eur Urol 2010;57:310-16. http://dx.doi.org/10.1016/i.eururo.2009.11.024

25. Lifshitz DA, Shikanov SA, Deklai T, et al. Laparoscopic partial nephrectomy for tumors larger than 4 cm: a comparative study. J Endourol 2010;24:49-55. http://dx.doi.org/10.1089/end.2009.0348

26. Van Poppel H, Da Pozzo L, Albrecht W, et al. A prospective, randomised EORTC intergroup phase 3 study comparing the oncologic outcome of elective nephron-sparing surgery and radical nephrectomy for low-stage renal cell carcinoma. Eur Urol 2011;59:543-52. http://dx.doi.org/10.1016/j.eururo.2010.12.013

Correspondence: Dr. Ricardo Rendon, Department of Urology, 5991 Spring Garden Rd, Suite 620, Halifax, NS B3H 1Y6; fax: 902-492-2437; rrendon@dal.ca

A key mission of CUAJ is to challenge readers with new concepts and provide new ideas and insights. Point/Counterpoint accomplishes this. The purpose of the section is to encourage vigorous and informed discussion on controversial issues in urology through the presentation of diverse opinions. We aim for a dispassionate discussion of controversies, recognizing that strong passions may exist in support of some positions. The positions presented may not necessarily reflect the personal opinion of the author or CUAJ. 